\title{
Faltering demand and performance of the logistics service sector in two cities of South-East Finland
}

\author{
OLLI-PEKKA K. HILMOLA AND ESA HÄMÄLÄINEN
}

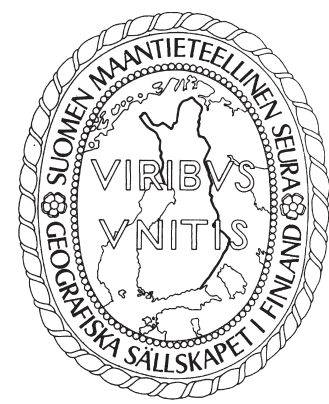

Hilmola, Olli-Pekka K. \& Esa Hämäläinen (2016). Faltering demand and performance of the logistics service sector in two cities of South-East Finland. Fennia 194: 2, 135-151. ISSN 1798-5617.

Emerging markets experienced strong growth since the years 2002-2003, and this was especially the case for import markets in Russia. Many border-sharing countries, as well as nearby sea ports, terminal areas and logistics service companies, benefited from it and revenue growth was the norm for years. This was also the case in Finland, more specifically for South-East cities such as Kotka and Kouvola. However, the situation changed in 2009, mostly due to the global credit crunch. The demand decline experienced then continued after a short recovery in 2010-2011. In this study, small and medium sized enterprises (SMEs) of the logistics service branch in the two Finnish cities will be analysed. The findings reveal that the sea port city (Kotka) suffered more from depressive demand, while a hinterland region (Kouvola) was able to switch from transit import and Russian import to more versatile logistics services. However, the situation is not straightforward, as transit export and railway volumes have maintained their levels rather well during the depression period.

Keywords: logistics services, SMEs, Finland, transit, foreign flows

Olli-Pekka K. Hilmola, Kouvola Unit, LUT School of Business and Management, Lappeenranta University of Technology, Prikaatintie 9, FIN-45100 Kouvola, Finland. E-mail: olli-pekka.hilmola@/ut.fi

Esa Hämäläinen, Brahea-Center, University of Turku, 20014 University of Turku, Finland.E-mail: esa.hamalainen@utu.fi

\section{Introduction}

After the Asian (Das 2012) and Russian currency (Chiodo \& Owyang 2002) crises of 1997-1998 and the end of the IT bubble burst (years 20022003), emerging markets around the world grew tremendously, and this was particularly the case for countries such as China and Russia. The Russian economy was actually growing at a rate of $5-10 \%$ per year and the currency was strengthening against main currencies such as USD (Mironov \& Petronevich 2015). Of course, economic growth was constantly present after the currency crisis in the late 90s, but fluctuations were wide in the early 2000. The growth period lasted approximately a decade and ended in late 2008. During the same period, domestic consumption grew considerably, as did the service sector (Mironov \& Petronevich
2015) and imported items were desired among consumers. All this created a demand for transit logistics services in nearby European Union member countries such as Poland, Lithuania, Latvia, Estonia and Finland (Märkälä \& Jumpponen 2009; Tapaninen \& Inkinen 2009; Bulis \& Skapars 2013). All of these countries benefited from Russian transit import flows until the end of the year 2008 as the market grew and price competition was not rigid.

However, after the 2009 economic slump some recovery took place, but in transit imports this meant that cheaper and better fit solutions took the lead. This typically led to container transportation chains favouring railways more than in the earlier growth era (e.g. Hilmola \& Henttu 2015; Hilmola \& Tolli 2015). It also had lower costs and, in turn, larger railway terminals were ready to handle in- 
coming containers on Russian soil. Furthermore, Russian sea ports developed significantly and were able to handle more import cargo than before (Korovyakovsky \& Panova 2011; Panova \& Korovyakovsky 2013). In regions and countries having higher operating costs, such as Finland, the recovery of 2010-2011 in transit imports of Russia was small, and thereafter the decline continued further. Studies before this change indicated that the Finnish route holds a cost disadvantage as compared to others, but on the other hand, location factors were reported to provide valuable added services for cargo (Märkälä \& Jumpponen 2009). The change had significant employment and business effects. Salanne et al. (2013) estimated that in 2008, transit transports employed some 3200 persons in Finland, while in 2012 they had declined to around 1200 employees. The reason behind this was mostly the transit imports decline and the loss of value added services to competitors, like those related to warehousing (Baker 2007). However, transit exports of raw materials to Europe have remained stable. The changes resulted in the decline of monetary benefits of transit by more than $60 \%$. A similar development path has occurred in Romania, an important hinterland transit country of Central European flows, where overall road transports declined from the 2008 peak by more than $50 \%$ in a two year time period, and recovery has thereafter been fragile (Popescu \& Fistung 2015). What is interesting in the Romanian case is the sustainability of railway transportation volumes, sharing similarity with Finland's decline in 2009, but with a consistent slow recovery thereafter, and in the end an increase in the modal share of total transports.

It should be remembered that Russian transit import is only one part of the equation as transit exports form the other side of the equation. The latter typically is not affected much by economic cycles, and can actually grow even in the middle of a recession. As transit export is, in the case of Russia, quite dependent on raw materials, its value added service content is low, and a need for modern warehousing services is therefore insignificant. However, not only are warehouses needed in much lower level and quality, but lower levels of road transportation services are also being sold, as transit export uses mostly railways. This was already apparent from the study by Salanne et al. (2013) with estimates concerning the year 2012 compared to the period starting from year 2005. The chosen region and two cities observed in this study, Kotka and Kouvola, were both vital points in transit import flows to the East. This can be highlighted by looking at data from 2007: the sea ports of Hamina and Kotka in this region handled $76 \%$ of transit import going through Finland (Lättilä \& Hilmola 2012). Apart from these two sea ports, Hanko was the third important player with a $20 \%$ share. These three together accounted for $96 \%$ of transit import from the East. Transit export figures are not as favourable to this examined region; typically, the sea port of Kokkola has dominated transit export, and Hamina and Kotka have had a smaller role, although in 2007 their combined share of transit export was 38\% (Lättilä \& Hilmola 2012).

This study concentrates on the South-East of Finland, which was experiencing a transit logistics boom during the pre-2009 years (Fig. 1). Growth was not only present in sea ports, but also within warehousing, freight forwarding, transportation, information technology and other value added services, and therefore hinterland locations benefited a lot (Posti et al. 2009; Salanne et al. 2013). Accessing the markets of the East is a cumbersome process, and hinterland locations could, through their warehouses, offer flexibility that sea port tied locations could not. Finnish logistics service SMEs are typically dependent on one sea port and its direct proximity as operations are centralised, and therefore routing is simply limited to this port alone (see empirical studies from Saranen 2010), but a hinterland location can conveniently use more than one port. Furthermore, border check points could be congested and facing queues at the border area, while hinterland warehousing locations can offer flexibility through other bordercrossing points, having longer distances from sea port warehouses. In addition, regulation changes regarding border-crossing and concerning product groups within different transport modes could change transportation chain configurations, and again locations with greater versatility and flexibility for routes and modes take the benefits. In an ideal world, warehousing and value added services are most prosperous near sea ports, but in uncertain markets the situation is not necessarily so.

In our research, we concentrate on two major locations in South-East Finland, one of them being a sea port city and the second one a hinterland city. In the pre-2009 era, they were both performing well in the field of logistics services, but after this prosperous period the situation suddenly changed into a faltering and depressive one. Some 


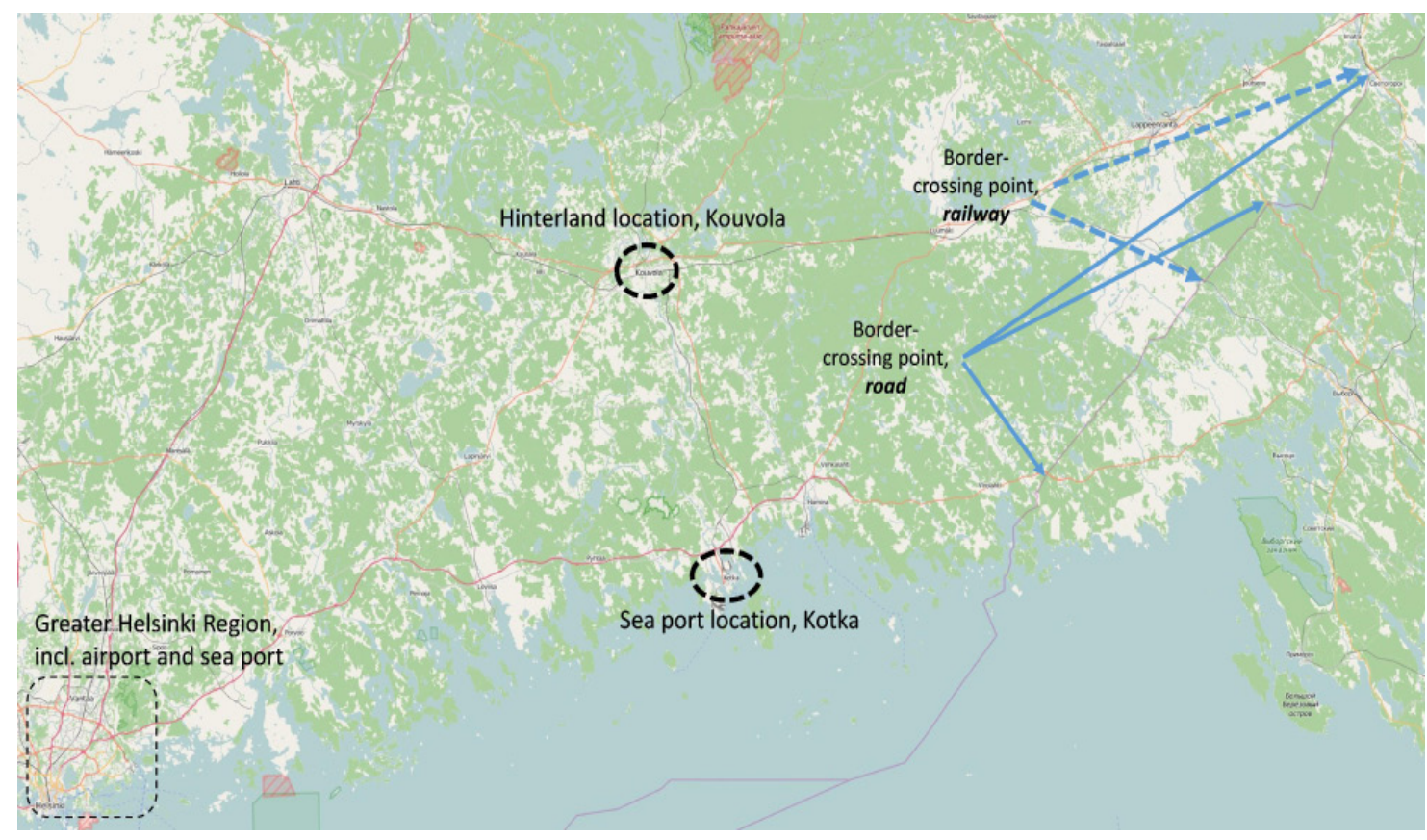

Fig. 1. Research environment: two South-East Finland cities and major border-crossing points and location of the Helsinki region. Source (map): Openstreetmap (2015), (c) OpenStreetMap contributors.

recovery has taken place in the domestic-led manufacturing export of Finland (in tons, not in export revenue), and in the Russian transit export. However, the lower value added items alone do not compensate for losses of transit imports for logistics services. In a study by Posti et al. (2009), the interview responses of logistics sector companies in Kouvola highlighted that they had a more positive future outlook even then. However, this was not due to transit opportunities, but to the Eastern export warehouse and logistics assets providing good railway connectivity at reasonable costs. Transit services in this region were considered to benefit most by near-by sea ports, like that of HaminaKotka. In some companies that participated in the Posti et al. (2009) study concerning transit as a business opportunity, it was shown that shares of transit revenues overall were high, even above $80 \%$. This was not the situation with all respondent companies from the locations of Kymenlaakso region including Hamina, Kotka, Kouvola and Virolahti or from Turku and Helsinki. According to Posti et al. (2009), six reported companies (corresponding to $42.9 \%$ of the respondents) had expo- sure to transit and profited from $21 \%$ out of revenues, while eight reported companies $(57.1 \%$ of respondents) did not have any exposure to transit flows.

The research problem in this study is related to a situation where a logistics service branch faces continued recession. Attention is focused on two regions, one hosting a sea port and one located in the hinterlands both having road and railway access. Two research questions are raised: 1) How have logistics service companies experienced the challenging and declining cargo market?; and 2) Does location play a role in the adaptation process? These two questions are being approached via second hand data from a variety of sources, including financial statements of small and medium sized companies, providing a perspective on the local development of logistics services.

The following section concentrates on the two studied Finnish sea ports serving Russian logistics flows. Hinterland transports volume analysis follows thereafter in a separate section; these are mostly reported from a Russian logistics flow perspective, but also featuring regional aspects from 
the point of view of our two cities of interest. After these two sections, the actual empirical part of this research concerning the two major cities serving logistics flows to the east is presented. Findings and discussion from the research work, containing warehouse space volume and price analysis, are also provided. The study is concluded in the final section, in addition to proposing further research avenues in this area.

\section{The Russian logistics market from Finnish perspective: sea ports}

In general opinion and atmosphere, Russian transit and, to a minor extent, other Eastern countries' transit through the sea ports of Finland is experiencing a significant decline, especially for containers, cars and semi-trailers. The tonnage being handled is roughly 75\% lower in 2015 when compared to the peak in 2008 within the sea port of HaminaKotka, the leading transit imports port (Fig. 2). However, on the other hand, transit export has grown slightly from $2008(11 \%)$, and more substantially compared to 2009 (31.8\%). In the case of HaminaKotka, the volume of transit import in the year 2015 was even significantly below the year 2009 level (-41.3\%). In general, transit transport handling in this sea port is fluctuating around 3-3.5 mil. tons per year, where some upwards tendency is built with spikes in 2008 and 2012.

In contrary to common economic trends, transit handling in another leading Finnish sea port, that of Kokkola, is on a long-term growth track (Fig. 3). It is surprising to find out that the volumes of early 2000 were within the level of some hundreds of thousand tons up to half a million, and these have grown and reached the range of 2.3-3.5 mil. tons in recent years. Handling volume consists mostly of transit export, as only tiny transit imports could be detected in the period of 2008-2013. Together with HaminaKotka's transit export, Kokkola's situation illustrates that transit export does not follow any particular economic condition or variable, but could even grow in the middle of crisis or recession periods. It should be noted that the year 2014 was a difficult one for the Russian domestic economy and also internationally due to sanctions set by different parties related to the dispute concerning Ukraine. The latest year in Figure 3 seems to be a year of decline also concerning transit export, and particularly Kokkola seems to experience dif- ficulties in terms of sustaining its earlier high volumes (indicating roughly one-third decline as shown in Fig. 3). HaminaKotka has also continued its decline, but to a smaller extent (total transit: $-8.7 \%$ in 2015).

Earlier research from the time period of 19782007 revealed a similar pattern to what has been detected in Figures 2 and 3 concerning transit export (Lättilä \& Hilmola 2012). This older analysis revealed that transit export did increase from below one million tons in the late 70s to nearly five million tons in 1994. This was despite the dissolution of the Soviet Union during 1991. Of course, the collapse of the last European empire caused some decline on transit exports during 1991-1992, but this was rather minor decrease. However, Lättilä and Hilmola (2012) did not find any independent variable to explain transit exports; one potential variable could have been lagged currency valuation, but explaining the reason remains an open question. Based on historical data, Lättilä and Hilmola (2012) argued that transit exports fluctuate from around two up to five million tons. As most of the transit export (88-95\% in recent years) flows through the analysed sea ports (Fig. 2, 3), it could be agreed that the situation has mostly remained the same. During the observation period, a minimum of 2.15 mil. tons was recorded in 2000, and a maximum of 5.88 mil. tons in 2014 . On average, during the period 2000-2014 transit export was 3.76 mil. tons.

The transit import of Russia, however, is driven by the domestic economy development of the country. Lättilä and Hilmola (2012) detected that the value of Russian oil exports drives the country's GDP, which in turn is the single driver of transit imports in Finnish sea ports. Together with the build-up of Russia's own sea ports for container handling (the main sea port of St. Petersburg handles 2-2.5 million twenty-foot equivalent units (TEUs) annually, while competitors in the Baltic States such as Klaipeda, Riga and Tallinn handle together one million TEUs); it is thus understandable that transit import has declined in such a large-scale fashion (Fig. 2, 3). The volumes reported in the time-period of 2009-2015 could be the new normal, and may not change unless the Russian economy experiences a major change in the coming years. This would, in reality, require oil prices to increase substantially, basically to the level of 100-150 USD per barrel. In addition, oil production should remain at the current high level. 


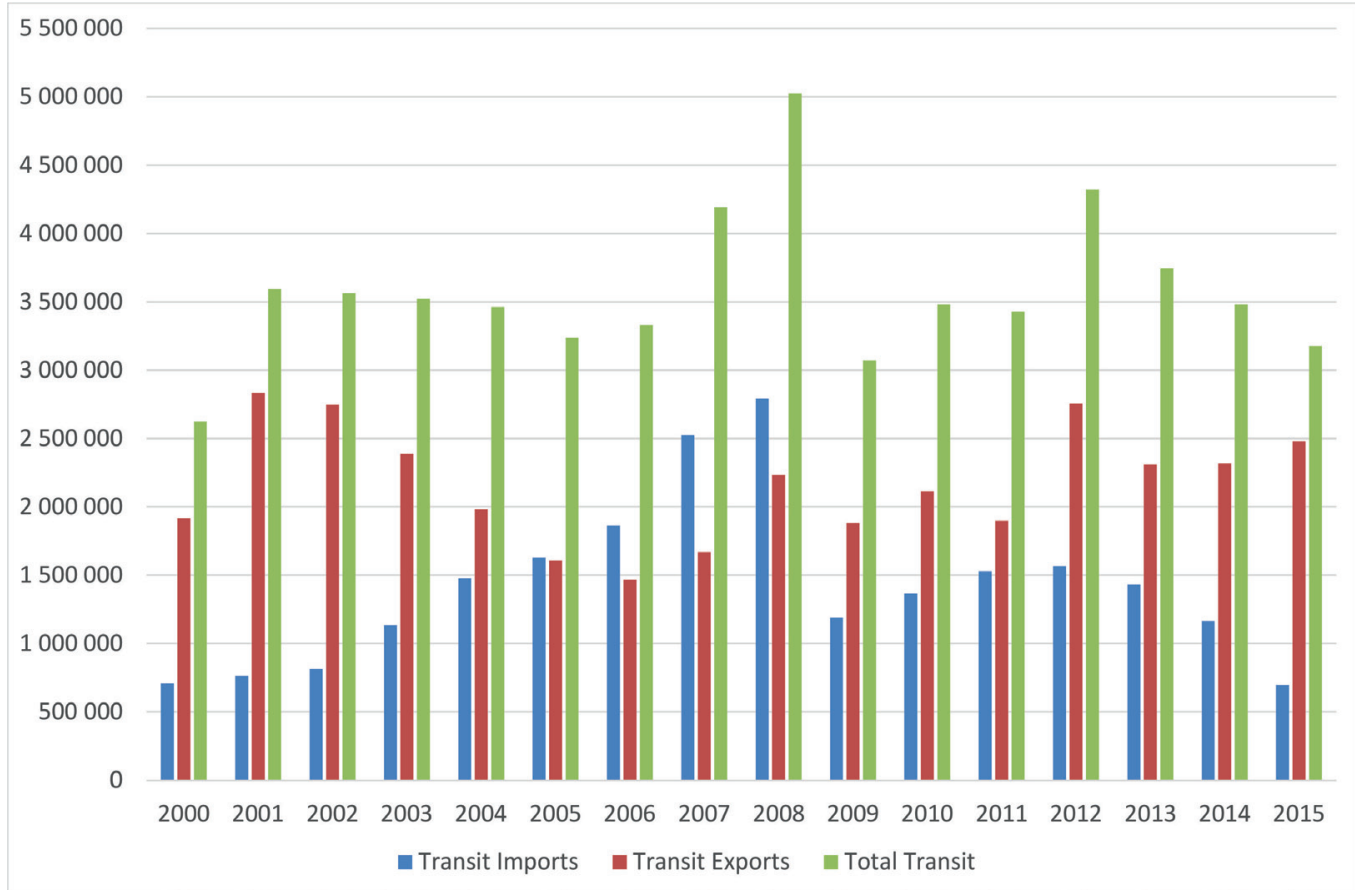

Fig. 2. Volume of sea port handling (tons) of transit export and import in the port of HaminaKotka (numbers prior to the year 2011 are combined from the individual ports of Hamina and Kotka) during the years 20002015. Source (data): Finnish Port Association (2016).

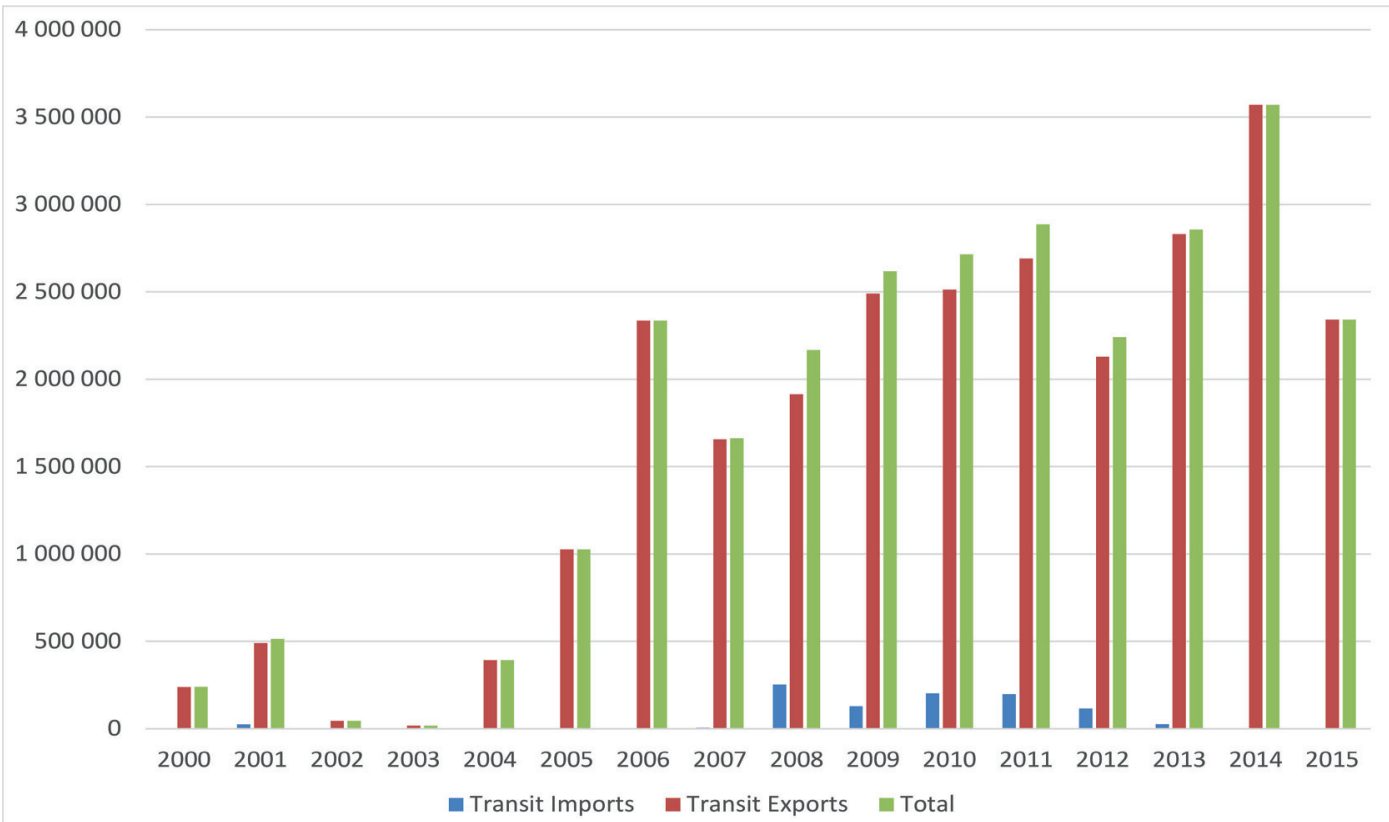

Fig. 3. Volume of sea port handling (tons) of transit export and import in the port of Kokkola during the years 2000-2015. Source (data): Finnish Port Association (2016). 


\section{The Russian logistics market from Finnish perspective: hinterland modes}

Regarding hinterland transport modes between Russia and Finland, it is necessary to add another component to the analysis: the foreign trade between these two countries. Therefore, the following analysis in road and railway transportation consists of export and import flows as well as transit. In general, it could be stated that when it comes to hinterland transportation modes, road transports have been severely hurt during the observation period, while railway transports have sustained their volumes. This difference is due to the fact that typically, import to Finland, together with Russian transit export, is accomplished using railways, while Finnish exports and Russian transit import are done with trucks. However, an exception to this is that in general the transport of wood from Russia to Finland is done using both trains and trucks.

As Figure 4 illustrates, the highest volume years in export and import based road transportation flows were in the period of 2002-2005. After this, volumes overall have only declined, and the level of 2009 has clearly been the new normal in road transports. Change overall from the best year in the observation period (2005) as compared to the year 2014 shows a decline of $31.2 \%$. Russian imports are the cause of this decline as their volumes have declined by nearly $45 \%$. Interestingly, Finnish export to Russia has not been hurt in terms of road transport volumes, as growth from 2005 to 2014 is $6.6 \%$; but in 2015 even this small growth ended. The decline in imports is mostly explained by the decline of wood import from Russia. However, this will change in the forthcoming years, as already shown in some short-term statistics, as the ruble has considerably weakened against the euro. Moreover, being a member of WTO, Russia applies low customs to wood trade; finally, effects are also due to the number of pulp production investments to be constructed, or soon to be finalised in Finland. It is interesting to note that in 2015 imports to Finland from Russia grew by $7 \%$. Finnish export volume by road to Russia in the most recent year was, in turn, not very good as sanc-

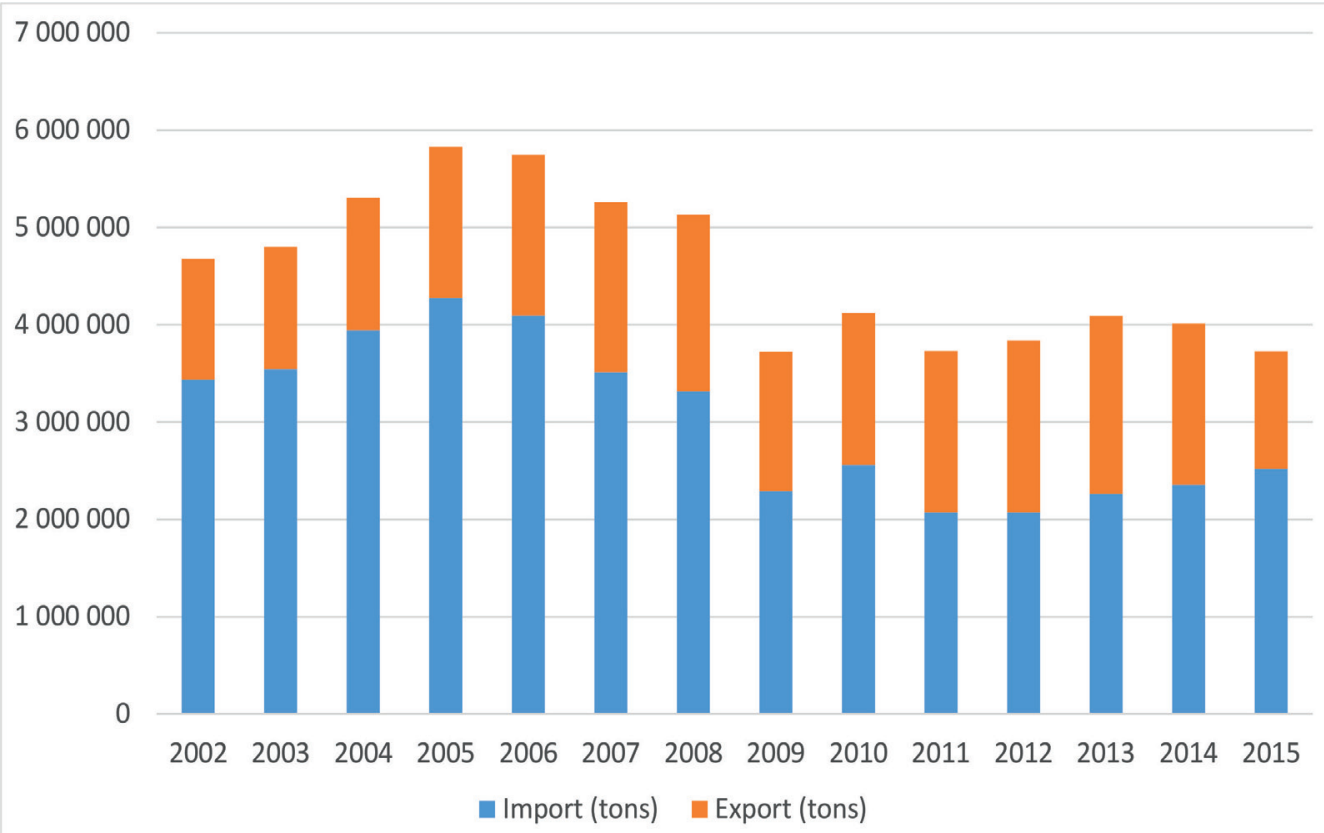

Fig. 4. Volumes of the road transports based on export and import of Finland to Russia (tons) during the years 2002-2015 (last year estimate with first seven-month volume). Source (data): Finnish Customs (2016). 
tions and economic hardship caused a significant decline by roughly $27 \%$.

Regardless of what the measure is for transit import, either from the border between Finland and Russia, or from Finnish sea ports, it could be concluded that transit has collapsed in this respect and the bottom seems to be much lower than the 2009 level; while a sharp decline continued in the year 2015. Based on Finnish Customs' (2016) transit statistics concerning border crossing with trucks, decline from the peak of 2008 is as steep as $79.4 \%$ (Fig. 5). General cargo tonnage for transit import has declined in sea ports by nearly $75.5 \%$ in the same period. All transit import in turn has declined in the period of $2008-2015$ by $78.3 \%$. Explanations for this situation are numerous and create a complex web of interactions. It is true that Russian consumption has declined during the same period, while oil price is currently down and dropped seriously in 2009, only recovering after global stimulus by Central Banks. However, a consumption plunge of $70-80 \%$ lower in the observation period is not realistic. Decline of the volume could be explained by other seaports competing for the transit volumes, but also by the fact that manufacturing volume has been constructed and taken in use within Russia for consumption items, like cars and related equipment. In the all-time high year of 2008 for transit import through Finland, the amount of cars imported through Finland amounted to 740,000 units (e.g. Merk et al. 2012). In 2014, this amount was well below 100,000 units, and the decline continued in 2015 vs. 2014 by more than $50 \%$ (Finnish Customs 2016). Therefore, it could be concluded that the collapse has been very severe in some product groups.

As already concluded in the sea port handling volume analysis, Russian transit exports have been strong and have relatively grown in the recent years. In the railway transportation mode, as shown in Figure 6, transit volumes have increased from the level of three to four million tons to nearly six million tons. The situation is not so good within plain import and export to east, especially with Russia. This is mostly explained by the decline of heavy industry production volumes, especially of paper in Finland during this period, and also by the increase of duties for imported wood

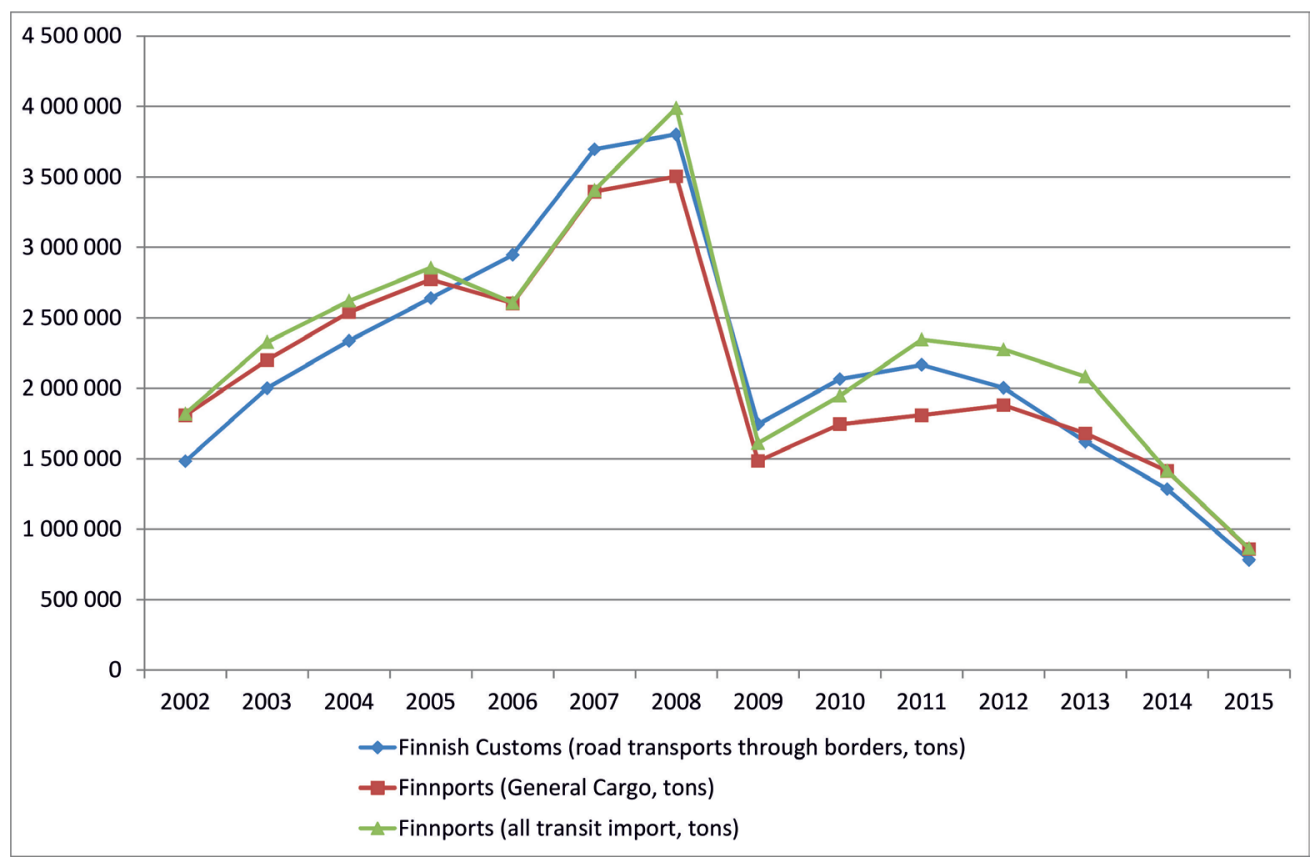

Fig. 5. Volumes of the road based transit transports (import) to Russia through Finland (tons) during the years 2002-2015. Source (data): Finnish Customs (2016); Finnish Port Association (2016). 


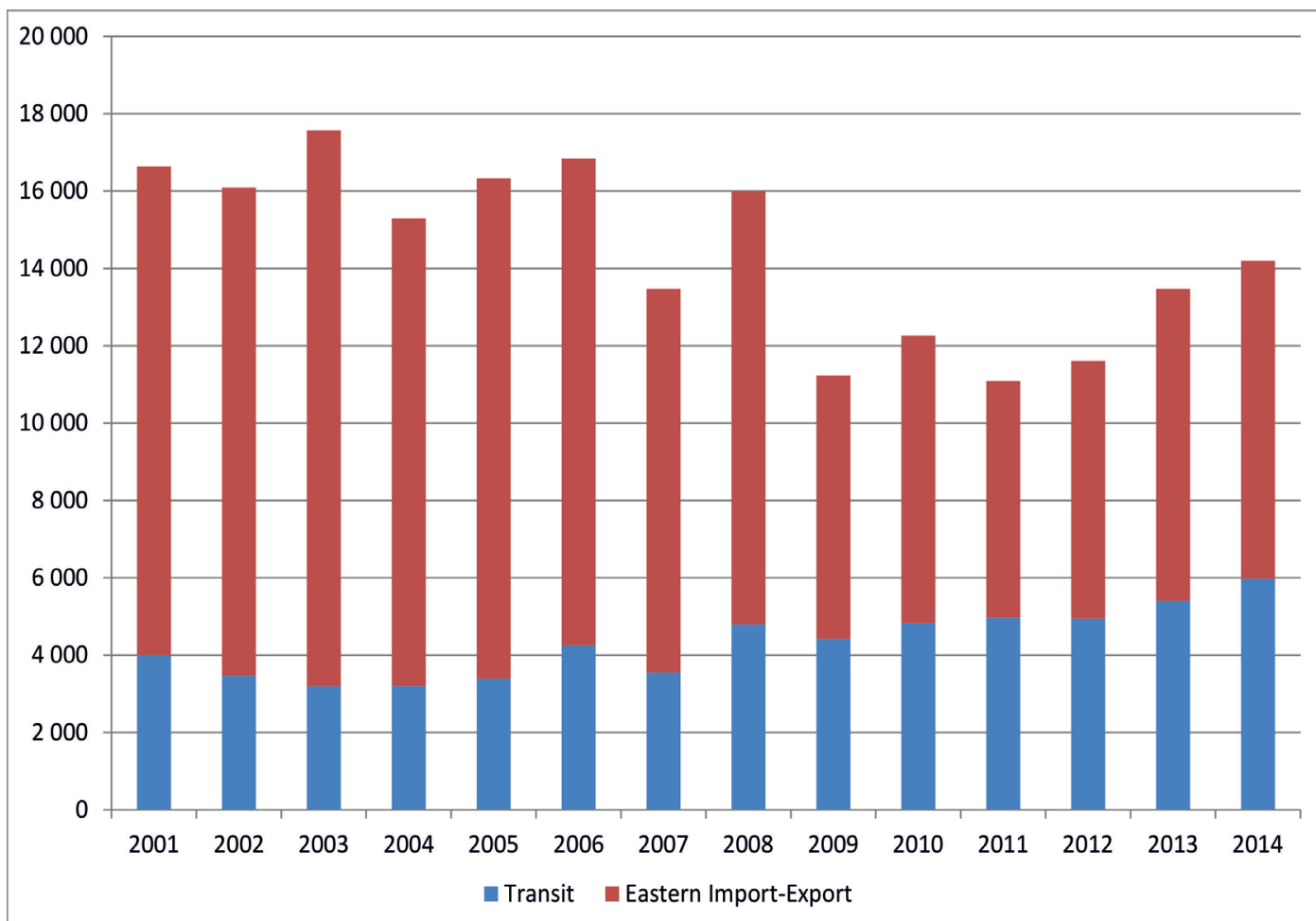

Fig. 6. Railway transportation volumes (tons) between Finland and Russia during the years 2001-2014. Source: Finnish Transport Agency (2015); VR (2014).

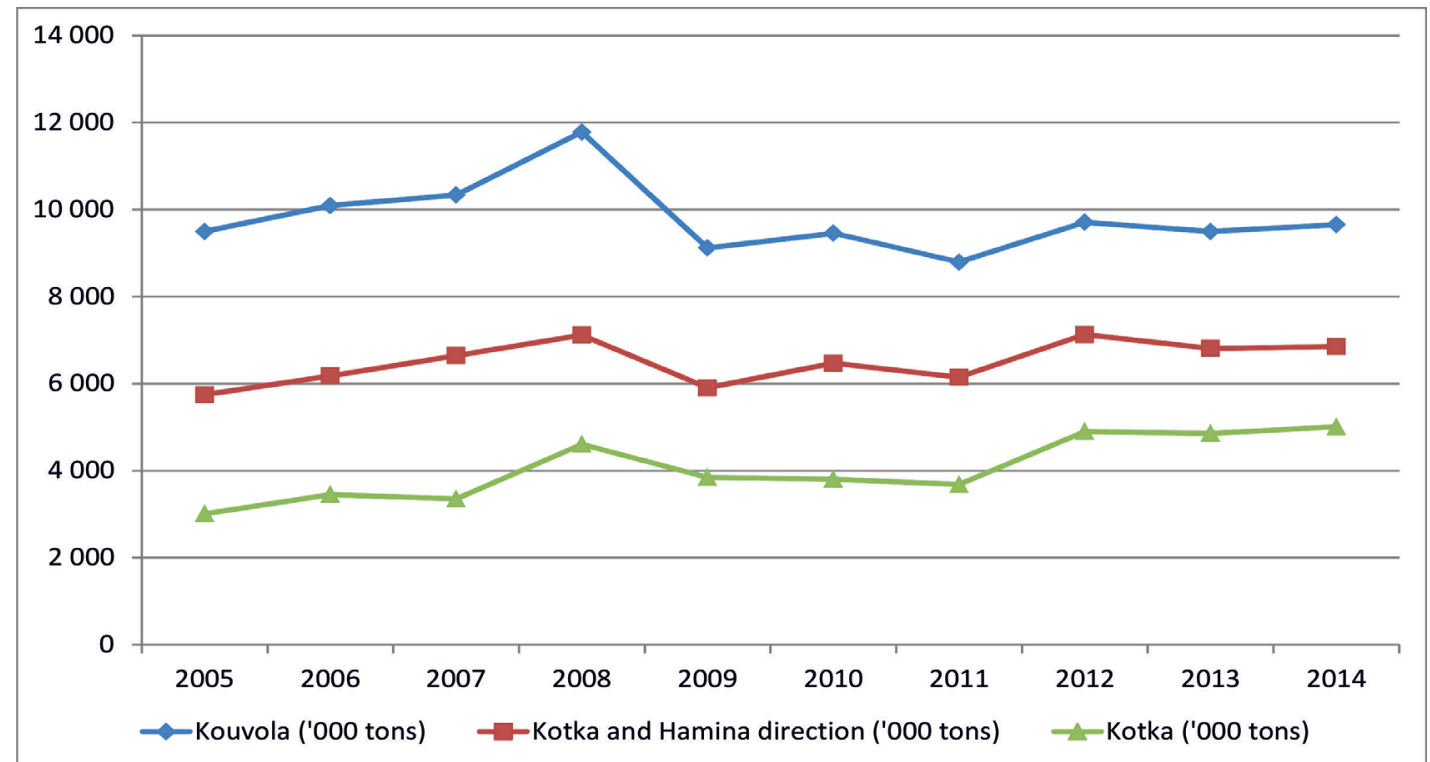

Fig. 7. Regional railway volumes ('000 tons) of Kouvola, Kotka and Hamina direction, and Kotka. Source: Finnish Rail Administration (2006, 2007, 2008, 2009); Finnish Transport Agency (2010, 2011, 2012, 2013, 2014, 2015). 
during 2007-2009. From the year 2003, importexport volumes have declined by $42.7 \%$ to the most recent year in Figure 6. However, some recovery has taken place after the slump of 2009, and volumes at railways are $20.9 \%$ higher in 2014. The year 2015 is not looking good for the railway transportation mode, but together with a general decline, some product groups are growing, such as the import of wood due to WTO membership of Russia, generally supporting a weak ruble and completed pulp production investments in Finland.

Although transit import and road transportation trade with Russia has been in trouble, and shown very steep declines, the overall situation in the researched region is not entirely depressive. Overall, railway volumes consisting of domestic, international and transit cargo have sustained their levels rather well (Fig. 7). Kouvola is practically at the same level as a decade ago (2014 vs. 2005). The railway line connection to the sea port cities of Kotka and Hamina has, in total, been growing, and to Kotka it has grown substantially $(+66.3 \%$ in the observation period: Fig. 7). This illustrates the dynamics of transportation modes simply and efficiently - in the post 2009-era bulk transports serving either Russian transit export or Finnish pulp and paper mills, are growing and showing sustainability. It is impossible to make a similar kind of analysis at a local level regarding road transports as most of the volume is domestic and soil transports for construction purposes use short distances, while statistics are available only at the regional level. In general, in South-East Finland the amount of trucks, or heavy transport units, on the roads (reported by the Finnish Transport Agency) has declined in recent years, and is somewhere at the level of early 2000. As said, this decline is a result of many factors, including lower domestic construction activity, the decline of transit imports to Russia, and the general decline of Russian trade.

\section{Situation in small and medium sized companies of the two cities}

Financial databases containing financial statements of logistics branch companies from our two cities of interest have been used as material for our research. The lookup was completed using postal codes (main logistics areas) and/or operating branch sub-sector codes (freight forwarding and transports, warehousing, road transports, and terminals for road transports) as well as city names (Kotka or Kouvola). All companies in the following analyses fulfil the criteria of SME, but some of the companies are only registered to Finland as a limited company, and are part of a larger global corporation. Most of the companies are, however, strictly SMEs, where affiliation to larger companies does not exist. Regarding the ownership of these companies it could be said that global companies are typically part of Central European corporations, while in SMEs the architype of owners is Finnish and/or Russian. Most of the companies in the following analysis from Kotka represent freight forwarding and transports (95.7\%), while in Kouvola's case this same sub-branch is the largest by a share of $50 \%$. The rest of the Kotka companies in the following analysis are from the warehousing sub-branch, while in Kouvola they represent road transports, terminals for road transports and warehousing. Therefore, with high confidence, it could be concluded that all of these companies are from the logistics service sector.

\section{Kouvola}

The hinterland city of Kouvola is located in SouthEast Finland (Fig. 1), and it is only a short distance from the HaminaKotka sea port (approx. 60-70 $\mathrm{km})$ and the Helsinki Vuosaari sea port (130-140 $\mathrm{km})$. The Helsinki-Vantaa airport is also only a short distance $(140 \mathrm{~km})$ away. The Russian border can be reached by truck through two major border-crossing points at a distance of $90-110 \mathrm{~km}$. Kouvola is also a major railway junction at a very short distance from the border-crossing point of Vainikkala $(91 \mathrm{~km})$ as well as Imatra $(130 \mathrm{~km})$. Railway connections also exist to various sea ports and cities as well as industrial plants. In the following section, companies that operate in one key terminal area located nearby a railway junction and main roads, will be analysed.

As with all other locations in the region during the pre-2009 era, Kouvola was performing well in the transit import business. It was the terminal area for the port of HaminaKotka, but the Trans-Siberian Railway connection also flourished and the city represented a distribution point for Asian electronics to Russia. This growth can be seen in Figure 8, where revenues roughly doubled among logistics SMEs in the period of 2005-2008. Profits also soared and in general all companies were showing good outcomes as illustrated in Figure 8 (except 
for two companies in 2008). However, the 2009 crash was really severe for these actors and revenues declined to the 2006 level. Companies' profitability suffered and it took three years for most of them to return to profits. Some companies are still in negative trend, and a turnaround remains to be seen in the future. In Figure 8 the amount of total profits in the year 2007 is exceptionally high, with one company actually accounting for the majority of this enormous increase. High profits came to this company most probably through asset sales. From the balance sheet it could be detected that in the year 2006 the company owned considerable assets that in the end of 2007 had disappeared;

40000

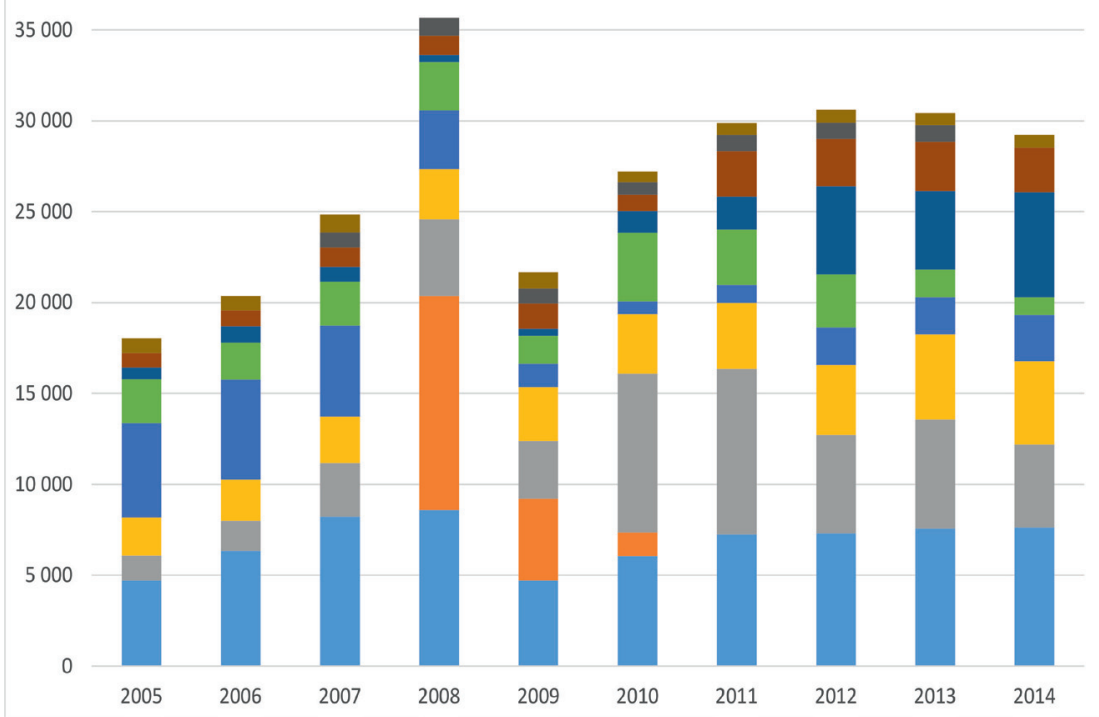

Fig. 8. Revenue ('000 euros) of different actors in small and medium sized logistics sector companies in Kouvola during period of 2005-2014 (n $=10)$. Source (data): Asiakastieto (2015).

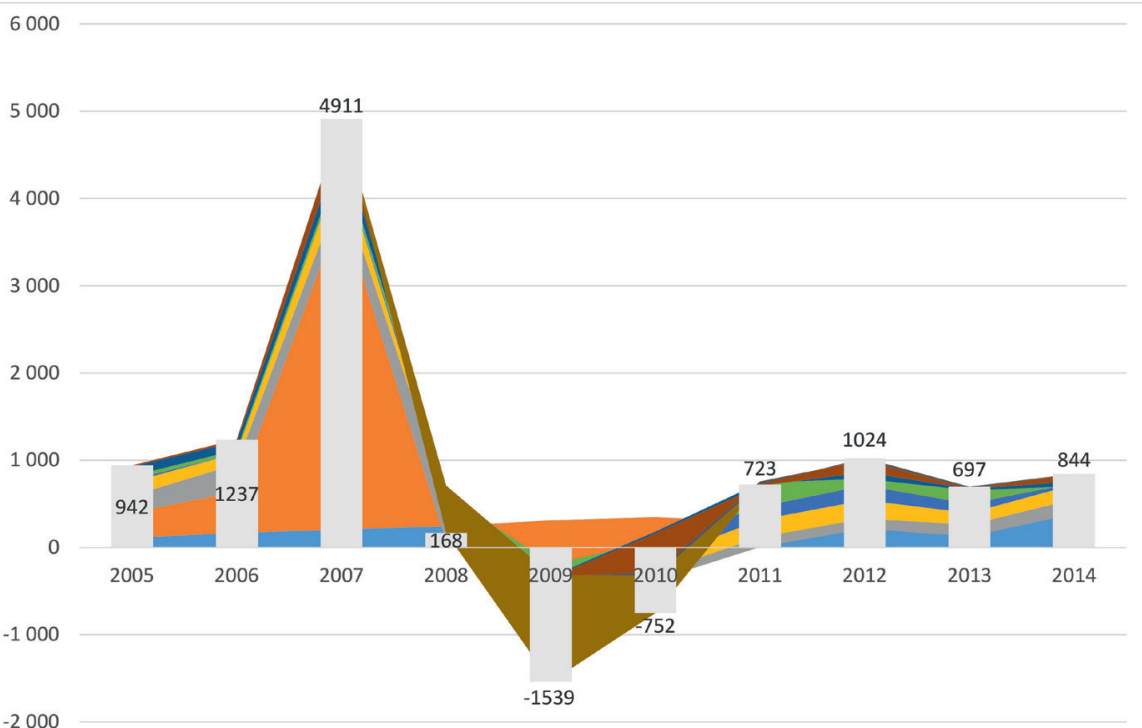

Fig. 9. Profit and loss ('000 euros) of different actors in small and medium sized logistics sector companies within Kouvola (stacked area) during the period 2005-2014 (n $=10$ ), and annual total of all companies (bar with number). Source (data): Asiakastieto (2015). 
extraordinary items contained income of $5.98 \mathrm{mil}$. euros and expenses of 1.34 mil. euros.

What is interesting concerning the companies analysed here is the fact that their revenues recovered from the 2009 slump. One daughter company of an international logistics service company held a major position in 2008 but disappeared completely from Kouvola and Finland after 2010. If this company is not taken into account, then the remaining companies together had already surpassed the revenue level of 2008 by 2011. Of course, this recovery has happened unevenly. Some companies, which were strong before, and employed a significant amount of people, have suffered a lot. Most of these were operating in Russian transit import or European export to Russia and other economies in the East. Companies also relied upon railway transport significantly. This combination seemed to have been weak for growth in a new era, while through Finland, in the Baltic States railways have been key factor for further growth (Hilmola \& Henttu 2015). However, the situation is changing, and it has changed. A lot of traditional industrial products from the pulp and paper industry are distributed through these companies to the East now, and import from the East as well as distribution to North European markets takes place rather frequently nowadays. Furthermore, local industrial production has partly recovered and provided business opportunities for the SMEs analysed here. It is important to note that only two companies out of the ten companies analysed are no longer any part of SMEs of Kouvola. As revealed earlier, one international player left this city and Finland after the year 2010, and a second company just ended operations in the year 2013. According to the received information, not a single company from these analysed actors have gone bankrupt. Of course, the companies had difficulties in 2009 as well as in the following year, but later many have been able to accumulate their assets significantly, and solvency is generally at a very good level. This development has been supported by consistent profit producing ability in the years 2011-2014 (Fig. 9).

\section{Kotka}

The reason for logistics service companies to exist in Kotka is of course linked to the short proximity to the HaminaKotka sea port (see Fig. 1 for details; also concluded in Posti et al. 2009). The city also has the same close proximity to the Helsinki Vu- osaari sea port (120-130 km) and Helsinki-Vantaa airport (130-140 km) as the earlier analysed Kouvola does. Material flow through a sea port city typically takes place through one key road based border crossing point, which is at a distance of below $70 \mathrm{~km}$. Railway transports to Russia proceed through Kouvola, and are experiencing some disadvantage, with additional 55-60 km needed in transportation to the border as compared to Kouvola (Fig. 1). In addition, other border-crossing points by road in the North are more distant than the earlier analysed city. Also, the number of companies is different in Kotka than in Kouvola, with 94 SMEs working in the logistics sector in Kotka, compared to ten SMEs in Kouvola. Companies are also much more international, counting some Russian affiliation in board members or with foreign and Russian CEOs.

Growth in business was even stronger among the analysed companies during the period 20052008 compared to Kouvola, as revenues tripled and reached a total level of 180 million euros (Fig. 10). Profits increased even more aggressively, and were nearly sevenfold higher in 2008 as compared to the base year (Fig. 11; 9589 thousand euro in 2014 vs. 1434 thousand euro in 2005). It could be detected that one automotive forwarding company produced slightly more than $50 \%$ of all profits in the years 2006, 2007 and 2008 (largest absolute profit among all companies in the analysed group). It is surprising that all of this profit was produced by operations, while asset sales or extraordinary items did not play any role. Passenger car transit to Russia was experiencing extremely high volumes and growth in this particular time, and reached an all-time high in 2008.

However, in 2009 the situation changed completely and has not recovered to what it was before. This was even the case where some of the biggest companies analysed are operating with bulk products and exports. Currently revenues are roughly of the peak in 2008, with a decline in revenues of $51.4 \%$. Profitability is at the level of 2005-2006, and actually without the three most profitable companies (a feeder shipper, a company handling bulk exports at sea ports, and one specialised in automotive sector cargo forwarding) the year 2014 would be clearly negative for the remaining group). Actually, this low profit development has continued since the 2009 collapse, as Figure 12 illustrates (excluding the three highest profit companies). Recovery was very weak, and the last three years in the observation period have 


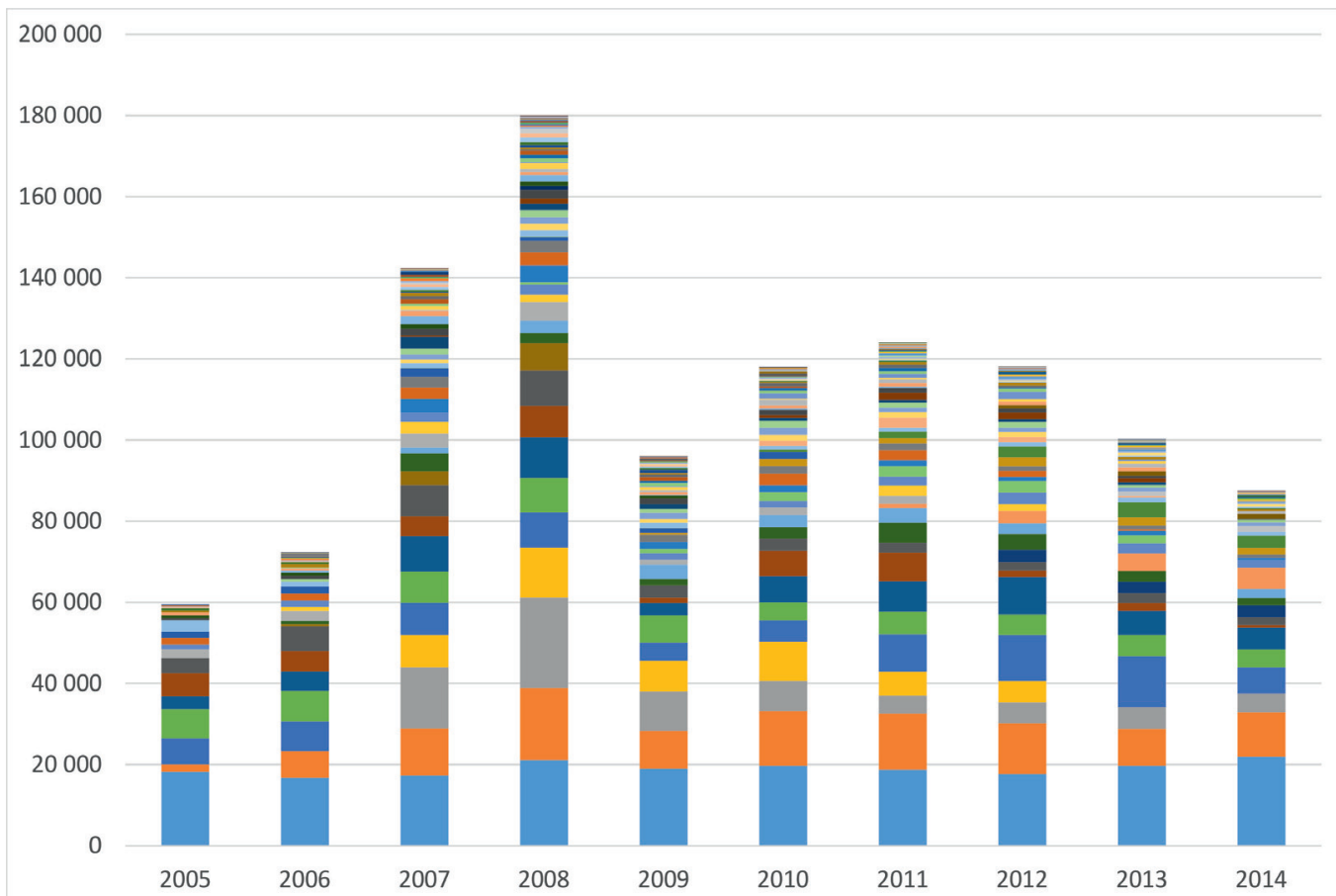

Fig. 10. Revenue ('000 euros) of different actors in small and medium sized logistics sector companies within Kotka during the period of 2005-2014 ( $\mathrm{n}=94)$. Source (data): Asiakastieto (2015).

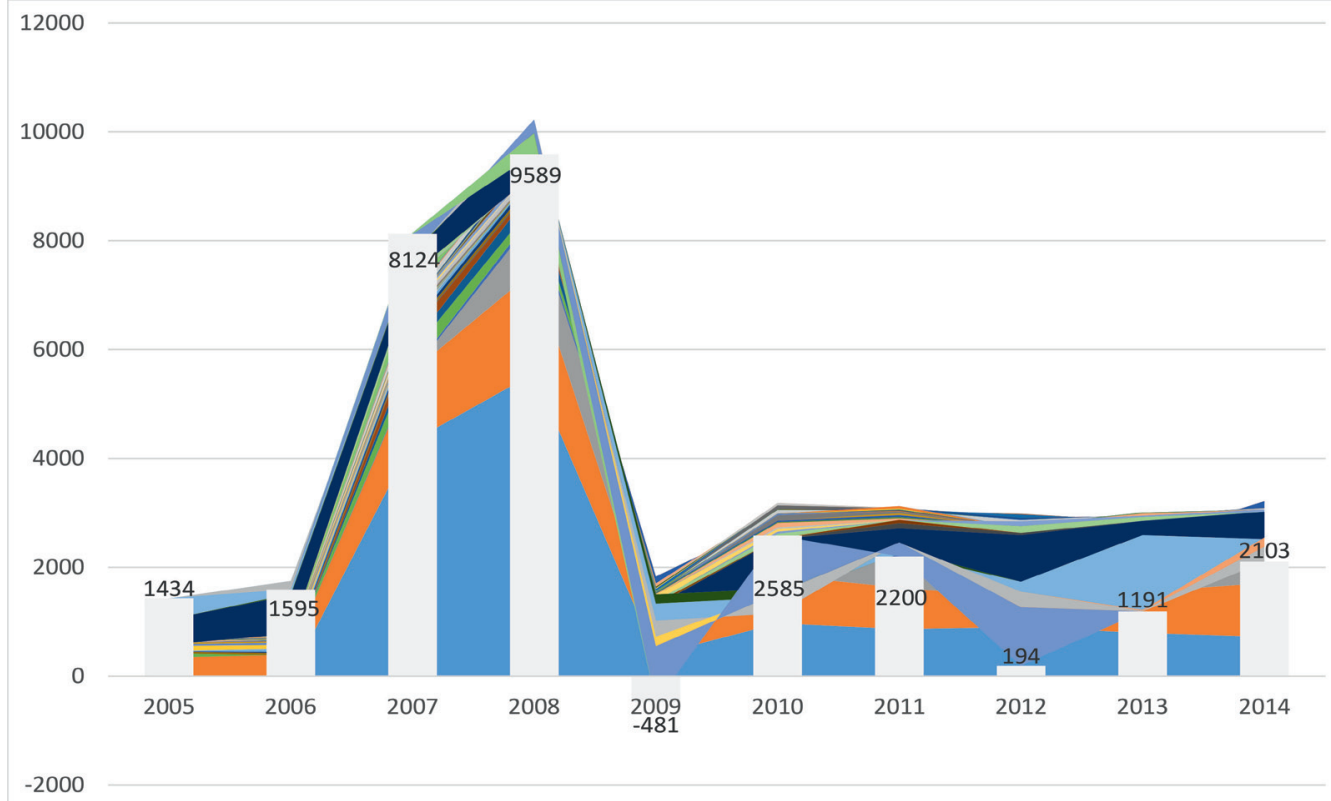

Fig. 11. Profit and loss ('000 euros) of different actors in small and medium sized logistics sector companies in Kotka (stacked area) in 2005-2014 ( $\mathrm{n}=94)$, and annual total of all companies (bar with number). Source (data): Asiakastieto (2015). 


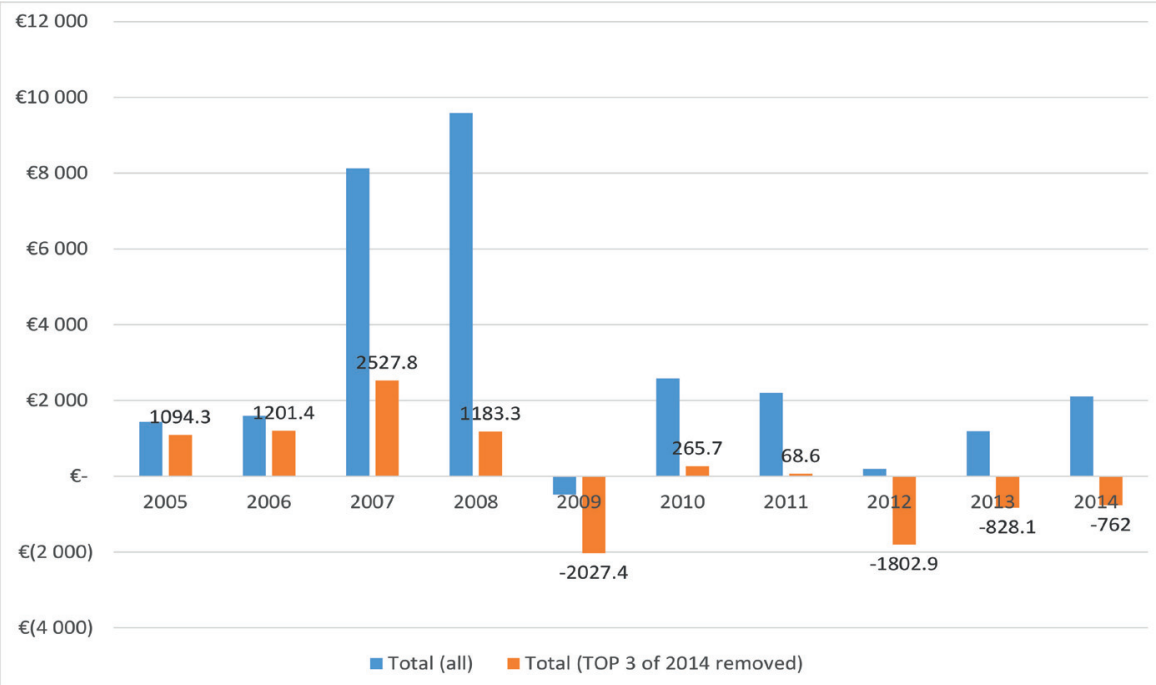

Fig. 12. Total profit and loss ('000 euros) of different actors in small and medium sized logistics sector companies in Kotka (stacked area) in 2005-2014 (n = 94), and another series, where the three most profitable companies are excluded from dataset. Source (data): Asiakastieto (2015).

been difficult. Some companies have gone out of business, and some are experiencing very serious difficulties in continuing their operations. In general, ground operations are experiencing a challenging situation. If transit import hardship continues in the forthcoming years, it is not difficult to predict that difficulties and bankruptcies will continue in Kotka.

\section{Discussion - warehousing investment perspective}

As previously discussed, the transit import of Russia was growing and showing considerable strength until 2009. This activity typically includes consumer goods, which are unitised (like containers or semi-trailers), and in these cases the role of value added services of logistics is high. To develop services within this area is not only in the interest of companies working in the branch, but it appears to be lucrative for the development of local economies and employment. To achieve these goals, companies and the public sector need to have low priced enlargement space available with the required building permissions. Investments cannot be realised over-night, and require years of strategic planning and commitment. Therefore, rapidly developing branches and volumes are prone to start and over-investment cycle due to time delays involved and possible misjudgement of the market development by decision makers. In Finland, the approach to investments has typically been proactive, differently from other bordering countries of Europe (Kovacs \& Spens 2006; Bulis \& Skapars 2013; Popescu \& Fistung 2015).

To have a macro-examination over the long-term development of warehousing establishment in the cities of interest, Table 1 was compiled from different national information sources. It could be noted that some cities such as Vantaa, Turku, Kotka, Seinäjoki, Hamina, Rauma and Hyvinkää have a much higher amount of warehousing capacity than their population would naturally grant it to be, meaning that rank in warehousing is much higher than rank in population. Naturally cities also exist where the role of warehousing is lower compared to the population rank, while it has higher importance in Espoo and Tampere. Closeness to a sea port and relatively low land cost explain the increase of warehouse capacity, and it is to be noticed that $\mathrm{m}^{2}$ cost depends from regions/counties, and not from cities. For example, land price in Vantaa is cheaper than in Helsinki or Espoo.

In light of Table 1, it could be concluded that warehousing infrastructure is most recent in those Finnish cities that are tied to Russian trade and transit. More than $60 \%$ of warehouse space was built in the year 1990 or afterwards in Kotka, Lap- 
peenranta and Hamina. A similar situation is present in Kouvola, where $57.1 \%$ of warehouse space was built in the same period of time. Observations from the newest warehousing capacity locations would be the same, if the period was shortened to start from the year 2000.

It is very difficult to say whether warehousing space built-up over-heated in Kotka as compared to Kouvola. If there was any significant difference between these two cities, it was in the period of 1990-1999. In that time, Kotka finalised 2.92 times more warehouse building space than Kouvola. In latter periods Kotka has been building in the same pace as Kouvola, although Kotka is much larger in overall warehouse space, and absolute numbers are significantly higher. This was especially the case in 2000-2009. Compared to other two cities in the region, Lappeenranta and Hamina, serving similar customer groups and logistics markets, Kotka and Kouvola did not expand very much after 2000. Kotka and Kouvola were both active in warehousing branch enlargement as others started to slow down their growth.

Trying to find an explanation for the difference in revenue and profit development difference between Kotka and Kouvola is difficult. Both were able to build new capacity during the expansion years. The difference regards the transformation and flexibility of the logistics industry in the region. In Kotka, companies have developed dependency from transit import and consumer items, while Kouvola from industrial, railway and raw material segments. Also, hinterland locations have more competitive contracts based on lower salaries compared to sea ports, where unions are strong. This has sustained economic profits of hinterland location with good connectivity.

What could these regions and business actors of the logistics sector, then, do differently in the future? The most important issue, based on this study, is the versatility of services and material flows being served. If all companies are concentrating and growing only through one sub-branch, it makes the region and city very vulnerable to changes of this single branch. What happened to transit import of Russia, could also happen to Finnish paper, pulp, wood and board industry. In addition, transit export could be hurt. It is vital that logistics sector actors represent and serve different material flow classes; this should already be secured in the land area rental and sales of the city during the early phases of warehouse construction projects. Even if the overall logistics branch is dominated by largescale international actors, the role of domestic

Table 1. Fifteen largest cities of warehousing building space in Finland, population rank, warehouse land cost (per building $\mathrm{m} 2$ ) and building periods. Yellow shaded rows denote cities within the influence region of logistics flows of this study. Source: National Land Survey of Finland (2015); Statistics Finland (2015).

\begin{tabular}{lccccccc}
\hline $\begin{array}{l}\text { Rank } \\
\text { warehousing }\end{array}$ & $\begin{array}{c}\text { Rank } \\
\text { population }\end{array}$ & $\begin{array}{c}\text { Warehouse land } \\
\text { cost }\left(€ / \mathrm{m}^{2}\right)^{*}\end{array}$ & City/region & $\begin{array}{c}\text { Warehouse buildings, } \\
\text { total space }\left(\mathrm{m}^{2}\right)\end{array}$ & $\begin{array}{c}\text { Taken to use 1990- } \\
\text { 1999, space }\left(\mathrm{m}^{2}\right)\end{array}$ & $\begin{array}{c}\text { Taken to use 2000- } \\
\text { 2009, space }\left(\mathrm{m}^{2}\right)\end{array}$ & $\begin{array}{c}\text { Taken to use 2010- } \\
2014, \text { space }\left(\mathrm{m}^{2}\right)\end{array}$ \\
\hline 1 & 4 & 270 & Vantaa & $1,6866,952$ & 267,112 & 406,214 & 139,492 \\
2 & 1 & 270 & Helsinki & $1,118,588$ & 112,234 & 195,196 & 36,678 \\
3 & 6 & 44 & Turku & 882,547 & 96,848 & 176,108 & 71,189 \\
4 & 19 & 16 & Kotka & 708,779 & 121,996 & 282,110 & 33,238 \\
5 & 2 & 270 & Espon & 597,603 & 72,504 & 32,306 & 42,217 \\
6 & 3 & 43 & Tampere & 578,006 & 92,066 & 78,026 & 12,385 \\
7 & 11 & 13 & Pori & 555,696 & 103,507 & 112,936 & 36,852 \\
8 & 5 & 19 & Oulu & 461,689 & 62,692 & 60,369 & 61,210 \\
9 & 10 & 16 & Kouvola & 395,924 & 41,756 & 164,261 & 20,164 \\
10 & 9 & 23 & Lahti & 368,628 & 50,051 & 66,751 & 30,521 \\
11 & 17 & 8 & Seinäjoki & 361,737 & 56,820 & 78,902 & 48,618 \\
12 & 13 & 34 & Lappeenranta & 347,665 & 80,191 & 122,742 & 31,761 \\
13 & 53 & 16 & Hamina & 346,388 & 117,066 & 113,804 & 4,390 \\
14 & 27 & 13 & Rauma & 314,535 & 73,358 & 37,899 & 11,639 \\
15 & 24 & 42 & Hyvinkää & 307,487 & 93,489 & 32,380 & 33,476 \\
\hline
\end{tabular}

*building $\mathrm{m}^{2}$ price (permission to build) of land 
SMEs within this industry should not be underestimated. In Kotka there was, and still is, a significant number of international companies working in this branch, from SMEs to part of corporations; while in Kouvola, companies are mostly domestically managed and owned. This probably acts as natural hedging for the latter region, as domestic owners are more risk averse than big corporations in the implementation of particular strategies. So, domestic SMEs could have better foresight about the future development and potential of some particular region than what is the case with others. This is valuable especially when drastic changes in demand take place.

\section{Conclusions}

Organisations in the private sector typically assume that growth is progressing and in the longterm occasionally happening declines will be dampened, with growth following some predetermined levels. This results in investment plans to serve customers in years' time. However, this management continuum has not been realised in the South-East Finland logistics service sector, which has been greatly dependent on Eastern transit and trade. Even though Russian transit export has been sustained through the economically difficult times within recent years, transit import has collapsed, and taken a considerable share from revenues and profits. This is particularly obvious in the sea port city logistics sector, where revenues have continued to decline below the 2009 slump level, and profits have been produced by a small number of companies. The situation is not as depressive within the hinterland city, where logistics service companies were able to recover by replacing transit import with other logistics service groups. Of course, the amount of companies in the latter city was much lower, over the entire observation period, and the sea port city really could be considered as a cluster around the port. In terms of profitability, the era before the 2009 slump was consistently producing profits, and profitability has been hard to develop thereafter. It could be stated, retrospectively, that the years 2007 and 2008 were exceptional, and it will take years for these kinds of situations to appear again.

As demand declines in certain sub-branches of logistics, service companies, particularly in transit import, have been severely hit. It is extremely interesting to try to assess what is the new normal level of demand in South-East Finland regarding logistics services. As discussed earlier, warehouse build-up in South-East Finland was brave not only in the time period of 2000-2009, but also the previous decade. Actually, cities such as Kotka, Hamina and Lappeenranta were very active in logistics sector capacity addition in 1990-1999. Now the level seems to be positioned around the volume experienced in the early 2000. Thus many cities have over-capacity in terms of warehousing sector buildings as well as infrastructure, and it will take at least a decade for this capacity to be absorbed. We could already see this from revenue and profit development of the two cities analysed, as well as from the statistics of transit import. Competition of the Finnish route is not necessarily any longer in the Baltic Sea Region as so much has been lost compared to other countries such as the three Baltic States and Poland. However, the future of South-East Finland within logistics services lies in the development of competing Eastern logistics flow routes. These are the Black Sea route and Trans-Siberian Railway connection of Russia to Asia. If either one of these experiences significant problems, then flows will be directed through the Baltic Sea Region, and will eventually also benefit South-East Finland. However, this equation is complicated, as general import activity of Russia has considerably declined due to sanctions set by different countries to themselves and to others.

In terms of further research, it would be interesting to continue following the development of transit and foreign trade flows of Russia and other nearby countries from the European Union countries' perspective. North-East Europe is dependent on its neighbours regarding long-term infrastructure investments of the logistics sector, and further growth requires more collaboration between different parties, not increasing the amount of isolation and/or sanctions. As currently emerging market currencies, including the Russian currency, are experiencing deep devaluations, it is evident that going back to old collaboration methods and a non-sanction world would make a significant impact on regional economies. If emerging market currencies stay low-valued, then this will correspond to more manufacturing and supply network activity. Substantial investments have already been made by various foreign countries such as Germany, and also Finland. This could enable increasing the amount of transit export, an interesting avenue for further research in the logistics service sector. 


\section{REFERENCES}

Asiakastieto 2015. Voitto+ CD ROM: Financial statement data from various years. Asiakastieto, Helsinki. <http://www.asiakastieto.fi/voitto/ohje/voitto1_eng.htm>

Baker $\bar{P}$ 2007. An exploratory framework of the role of inventory and warehousing in international supply chains. International Journal of Logistics Management 18: 1, 64-80. http://dx.doi.org/10.1108/09574090710748171.

Bulis A \& Skapars R 2013. Development of international freight transit in Latvia. Procedia - Social and Behavioural Sciences 99, 57-64. http://dx.doi.org/10.1016/j.sbspro.2013.10.471.

Chiodo AJ \& Owyang MT 2002. A case study of a currency crisis: the Russian default of 1998. The Federal Reserve Bank of St. Louis Review 84: 6, 7-18.

Das S 2012. Traders, guns and money. Financial Times Publishing, Great Britain.

Finnish Customs 2016. Uljas database (logistics subsection). Helsinki, Finland. <http://uljas.tulli.fi> Accessed March 2016.

Finnish Port Association 2016. Annual and monthly statistics. Helsinki, Finland. <http://www. finnports.com/eng/statistics/?stats=yearly> Accessed March 2016.

Finnish Rail Administration 2006. The Finnish railway statistics. Statistics from the Finnish Rail Administration. Helsinki, Finland.

Finnish Rail Administration 2007. The Finnish railway statistics. Statistics from the Finnish Rail Administration. Helsinki, Finland.

Finnish Rail Administration 2008. The Finnish railway statistics. Statistics from the Finnish Rail Administration. Helsinki, Finland.

Finnish Rail Administration 2009. The Finnish railway statistics. Statistics from the Finnish Rail Administration. Helsinki, Finland.

Finnish Transport Agency 2010. The Finnish railway statistics. Statistics from the Finnish Transport Agency, No. 6. Helsinki, Finland.

Finnish Transport Agency 2011. The Finnish railway statistics. Statistics from the Finnish Transport Agency, No. 5. Helsinki, Finland.

Finnish Transport Agency 2012. The Finnish railway statistics. Statistics from the Finnish Transport Agency, No. 4. Helsinki, Finland.

Finnish Transport Agency 2013. The Finnish railway statistics. Statistics from the Finnish Transport Agency, No. 9. Helsinki, Finland.

Finnish Transport Agency 2014. The Finnish railway statistics. Statistics from the Finnish Transport Agency, No. 2. Helsinki, Finland.

Finnish Transport Agency 2015. The Finnish railway statistics. Statistics from the Finnish Transport Agency, No. 6. Helsinki, Finland.

Hilmola O-P \& Henttu V 2015. Border-crossing constraints, railways and transit transports in Estonia.
Research in Transportation Business \& Management 14, 72-79.

http://dx.doi.org/10.1016/j.rtbm.2014.10.010.

Hilmola O-P \& Tolli A 2015. Early 2015 performance in Baltic Sea ports: forecasts of Estonian performance for entire year. Journal of Transport and Telecommunication 16: 3, 183-189.

http://dx.doi.org/10.1515/ttj-2015-0016.

Korovyakovsky E \& Panova Y 2011. Dynamics of Russian dry ports. Research in Transportation ECOnomics 33: 1, 25-34.

http://dx.doi.org/10.1016/j.retrec.2011.08.008.

Kovacs G \& Spens KM 2006. Transport infrastructure in the Baltic States post-EU succession. Journal of Transport Geography 14: 6, 426-436. http://dx.doi.org/10.1016/j.jtrangeo.2006.01.003.

Lättilä L \& Hilmola O-P 2012. Forecasting long-term demand of largest Finnish sea ports. International Journal of Applied Management Science 4: 1, 52-79. http://dx.doi.org/10.1504/IJAMS.2012.044871.

Merk O, Hilmola O-P \& Dubarle P 2012. The competitiveness of global port-cities: the case of Helsinki - Finland. OECD Regional Development Working Papers 2012/08.

http://dx.doi.org/10.1787/5k92z70x5v7g-en.

Mironov VV \& Petronevich AV 2015. Discovering the signs of Dutch disease in Russia. Resources Policy 46: 2, 97-112.

http://dx.doi.org/10.1016/j.resourpol.2015.09.007.

Märkälä M \& Jumpponen J 2009. Transit traffic route selection - a comparison of the transit routes to Russia from a company viewpoint. World Review of Intermodal Transportation Research 2: 4, 264-278.

http://dx.doi.org/10.1504/WRITR.2009.026207.

National Land Survey of Finland 2015. Real estate sales in 2014. National Land Survey of Finland. Helsinki, Finland. <http://www.maanmittauslaitos.fi/sites/default/files/kiinteistojen_kauppahintatilasto_2014.pdf> Accessed August 2015.

Openstreetmap 2015. Open street map service webpage and application. <https://www.openstreetmap.org $>$ Accessed November 2015.

Panova Y \& Korovyakovsky E 2013. Perspective reserves of Russian seaport container terminals. World Review of Intermodal Transportation Research 4: 2/3, 175-193. http://dx.doi.org/10.1504/WRITR.2013.058979.

Popescu T \& Fistung FD 2015. Freight transports in Romania, between desires and achievements. Past, present and future. Procedia Economics and Finance 22, 304-312. http://dx.doi.org/10.1016/S2212-5671(15)00291-9.

Posti A, Ruutikainen P, Haapakangas E-L \& Tapaninen U 2009. TRALIA - transitoliikenteen lisäarvopalvelut [TRALIA - value added services of transit transports]. Publications from the Centre for Maritime Studies, University of Turku, B 164. X, Turku.

Salanne I, Tikkanen M \& Leskinen T 2013. TRAMA The economic effects of transit transport - Results 
report 2013. Publications of the Ministry of Transport and Communications, 44/2013. X, Helsinki.

Saranen J 2010 (ed). Intermodal transportation in emergency situations in the Gulf of Finland. Research Report 223. Department of Industrial Management, Lappeenranta University of Technology, Lappeenranta.

Statistics Finland 2015. Buildings database with respect of main purpose of use and year of finalizing construction. <http://tilastokeskus.fi/til/rakke/ tau.html> Accessed June 2015.
Tapaninen $U$ \& Inkinen T 2009. Finnish-Russian transport and business expectations. World Review of Intermodal Transportation Research 2: 4, 279-295.

http://dx.doi.org/10.1504/WRITR.2009.026208.

VR 2014. Annual report of VR group. <http://www. vrgroupraportti.fi/en/annual-report-2014/> Accessed September 2015. 